\title{
EDN2 Gene
}

National Cancer Institute

\section{Source}

National Cancer Institute. EDN2 Gene. NCI Thesaurus. Code C24358.

This gene is involved in vasoconstriction and macrophage chemotaxis. 